\title{
The use of cumulative gas and volatile fatty acid production to predict in vitro fermentation kinetics of Italian ryegrass leaf cell walls and contents at various time intervals
}

\author{
Jeroen C. J. Groot ${ }^{1}$, Barbara A. Williams ${ }^{2 *}$, Arno J. Oostdam ${ }^{2} \dot{\uparrow}$, Huug Boer $^{2}$ and Seerp Tamminga ${ }^{2}$ \\ ${ }^{1}$ C.T. de Wit Graduate School for Production Ecology, Department of Agronomy, Agricultural University, Haarweg 333, \\ 6709 RZ Wageningen, The Netherlands \\ ${ }^{2}$ Wageningen Institute of Animal Science, Animal Nutrition Group, Agricultural University, Marijkeweg 40, 6709 PG \\ Wageningen, The Netherlands
}

(Received 9 August 1996-Revised 2 October 1997-Accepted 5 December 1997)

\begin{abstract}
Differences between the fermentation characteristics of cell contents $(\mathrm{CC})$ and protease-treated cell walls (CW) of young leaves of Italian ryegrass (Lolium multiflorum Lam.) cultivar Multimo (tetraploid), were studied in vitro. Gas and volatile fatty acid (VFA) production rates were measured at regular intervals, as was the degradability of organic matter (OM) of CW. The measured VFA were used to predict the gas production and fermentable OM using stoichiometric calculations. For $\mathrm{CW}$ the volume and kinetics of measured gas production were the same as those predicted from the VFA formed. In contrast, the measured gas production for $\mathrm{CC}$ was consistently less than predicted, indicating that the stoichiometric equations were not valid for rapidly fermenting substrates. For both $\mathrm{CC}$ and $\mathrm{CW}$, the relative rate of acetic acid production levelled off more slowly than for other VFA, resulting in an increasing gas yield (in $\mathrm{ml} / \mathrm{g}$ fermentable OM) after $12(\mathrm{CW})-24(\mathrm{CC}) \mathrm{h}$ incubation. Consequently, the fermentation of $\mathrm{OM}$ was not linearly related to gas production kinetics. For $\mathrm{CW}$, the kinetics of decline of degradable $\mathrm{OM}$ and fermentable $\mathrm{OM}$ were the same, after correction for a constant 'lost fraction' of degradable OM of $205 \mathrm{~g} / \mathrm{kg}$ OM. This work indicates the value of detailed studies of fermentation processes to evaluate herbage quality. In particular, the role of $\mathrm{CC}$ and the difference between degradation and fermentation require further attention.
\end{abstract}

Fermentation: Grass: Volatile fatty acids

Forages are usually evaluated using in vitro and in situ methods (e.g. Erwin \& Elliston, 1959; Tilley \& Terry, 1963; Goering \& Van Soest, 1970; Ørskov et al. 1980). However, the degradation of feedstuffs in the rumen requires sequential processes of solubilization and fermentation. Both processes depend on the chemical composition and structure of the substrate (Salvador et al. 1993; Merchen \& Bourquin, 1994). Solubilization of cell walls requires hydration, colonization by rumen micro-organisms and then the release of enzymes from these micro-organisms, to digest the complex cell-wall structures (McAllister et al. 1994). These processes result in degradation of cell walls. The in vitro and in situ techniques now in use have the disadvantage that the contribution of the soluble components of the original feed cannot be assessed, since they rely mainly on the measurement of particle loss. Fermentation, on the other hand, is the anaerobic decomposition of substrates by micro-organisms and can be assessed according to the production of end-products, of which volatile fatty acids (VFA) and gas are the most important (Lin et al. 1985). At present, cumulative gas production is increasingly being used to measure the fermentation kinetics of ruminant feeds (Beuvink \& Spoelstra, 1992; Pell \& Schofield, 1993; Theodorou et al. 1994).

The complex interactions within a mixed rumen microbial population leading to the conversion of plant components to gas and VFA, have been summarized in the form of stoichiometric reaction equations (Wolin, 1975, 1979; Russell \& Wallace, 1988; Van Soest, 1994). All of the equations show the relationship between the hexose-

\footnotetext{
Abbreviations: $\mathrm{CC}$, cell contents; $\mathrm{CW}$, protease-treated cell walls; NDF, neutral-detergent fibre; OM, organic matter; VFA, volatile fatty acids * Corresponding author: Dr Barbara A. Williams, fax +31 317 484260, email Barbara.Williams@ALG.VV.WAU.NL

$\dagger$ Present address: Cehave n.v., PO Box 200, 5460 BC Veghel, The Netherlands.
} 
equivalents fermented, and the proportions of fermentation products produced. Such equations have been used to estimate the extent of digestion of hexose-equivalents on the basis of the fermentation products formed (e.g. Blümmel \& Ørskov, 1993).

The aim of the present work was to investigate the dynamics of degradation and fermentation of the proteasetreated cell walls (CW) and cell contents (CC) of the leaves of Italian ryegrass (Lolium multiflorum). Gas and VFA production rates were measured at regular intervals throughout incubation. The VFA data obtained during fermentation were used in stoichiometric equations to predict both organic matter (OM) disappearance and formation of gas. The predicted values were then compared with those measured, to determine whether cumulative gas production reflected changes in other fermentation variables, including VFA and the disappearance of OM.

\section{Materials and methods}

\section{Substrates and cumulative gas production}

Italian Ryegrass (Lolium multiflorum Lam., tetraploid cultivar Multimo) was sown on 28 October 1993. The seeding rate was nine plants per pot $\left(0.0169 \mathrm{~m}^{2}\right.$ surface area) containing a mixture of sand and peat $(1: 1, v / v)$. The plants were grown in a heated glasshouse, at day and night temperatures of 18 and $13^{\circ}$ respectively. Day temperatures were maintained between 08.00 and 20.00 hours. Day length was natural, and the relative humidity was approximately $70 \%$. Additional light was supplied by Philips 400W SONT lamps (Philips, Eindhoven, The Netherlands) for $14 \mathrm{~h} / \mathrm{d}$. The pots were placed in large trays, which were flushed with nutrient solution (Steiner, 1984). The pots were placed in two replicate blocks. Plants were harvested after $113 \mathrm{~d}$ of growth, when they had formed eight leaves on the main stem (18 February 1994). The last fully expanded leaf was dissected from the main stem of each plant and frozen separately before analysis.

\section{Cell wall and contents fractionation, and cumulative gas production}

Fresh leaves were first chopped into $10-20 \mathrm{~mm}$ pieces using a paper guillotine and then further chopped in a Knifetec Sample Mill (Tecator, Sweden). This material was pressed (HAPA hydraulic press, IKA, Germany; $250 \mathrm{ml}$ ) through a double nylon cloth (Nybolt PA 40/30, Zurich, Switzerland) under a pressure of $10100 \mathrm{kPa}$. The residue was mixed thoroughly with distilled water, and the process repeated three times. The resultant filtrate was cooled with solid $\mathrm{CO}_{2}$, while the residue was washed. Both components were freeze-dried and ground through a $1 \mathrm{~mm}$ sieve (Retsch mill, Haan, Germany). The residue was then treated with neutral detergent (Goering \& Van Soest, 1970) and protease (Sigma Protease Type XXIIl P-4032; Sigma, St Louis, MO, USA) resulting in the $\mathrm{CW}$ fraction. The protease treatment lasted for $1 \mathrm{~h}$ in $60 \mathrm{ml}$ phosphate buffer containing $0.25 \mathrm{ml}$ protease $/ \mathrm{g}$ DM.

Two replicate samples were incubated for cumulative gas production measurements during various incubation periods, according to the method of Theodorou et al. (1994). Bottles containing CC were removed at 3, 6, 12, 24, 48 and $120 \mathrm{~h}$ after inoculation, while the $\mathrm{CW}$ removal times were $6,12,24,48,72$ and $120 \mathrm{~h}$. The fermentation was stopped by plunging the bottles into iced water for $20 \mathrm{~min}$. A liquid sample was then collected for VFA analysis and the residual $\mathrm{CW}$ estimated by filtration through sintered glass crucibles (Schott Duran, porosity no. 2, Mainz, Germany) and rinsing with hot water. Blank bottles containing only medium and inoculum, but no substrate, were incubated for $120 \mathrm{~h}$.

\section{Chemical and volatile fatty acid analysis}

Neutral-detergent fibre (NDF; Goering \& Van Soest, 1970), crude protein and ash were determined according to standard procedures. VFA were analysed using GLC (Packard 419, (CE Instruments, Milan, Italy), glass column filled with Chromasorb 101, carrier gas $\mathrm{N}_{2}$ saturated with methanoic acid, $190^{\circ}$ with isocaproic acid as the internal standard).

\section{Stoichiometric calculations}

The theoretical stoichiometric calculations used to obtain an approximate indication of OM fermentation, were based on the VFA production measured at each time interval (Van Soest, 1994). OM fermentation was expressed in glucose equivalents (g). It was assumed that the glucose equivalents were fermented to form the end-products: acetic (HAc), propionic (HPr), and butyric acids ( $\mathrm{HBu}$ ), and the gases $\mathrm{CO}_{2}$ and $\mathrm{CH}_{4}$, as well as being incorporated into microbial biomass.

To calculate the amount of glucose required for microbial growth, the amount of ATP $(\mathrm{mmol})$ synthesized can be estimated from the VFA production. VFA production results in direct gas production $(1 \mathrm{mmol}$ from acetic acid and $2 \mathrm{mmol}$ from butyric acid; Hungate, 1966; Beuvink \& Spoelstra, 1992). To estimate ATP production for microbial growth, the molar proportions of $\mathrm{CO}_{2}$ and $\mathrm{CH}_{4}$ in the gas produced also need to be derived. From stoichiometric equations it can be calculated that:

$$
\begin{aligned}
& \mathrm{CO}_{2}=\frac{\mathrm{HAc}}{2}+\frac{\mathrm{HPr}}{4}+\frac{3 \mathrm{HBu}}{2}, \\
& \mathrm{CH}_{4}=\mathrm{HAc}+2 \mathrm{HBu}-\mathrm{CO}_{2} .
\end{aligned}
$$

The production of microbial biomass was estimated from the total ATP production (2, 3 and $3 \mathrm{~mol} / \mathrm{mol}$ acetic, propionic and butyric acids respectively) and the yield of microbial biomass per mol ATP ( $\mathrm{Y}_{\mathrm{ATP}}$, assumed to be constant at $10 \mathrm{mg} / \mathrm{mmol}$ ATP; Hespell, 1979). It was assumed that $80 \%$ of bacterial structures were synthesized from glucose skeletons. The glucose consumption for production of biomass (Glucose biomass ) and for production

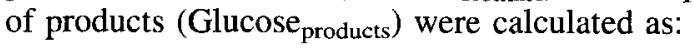

$$
\begin{aligned}
\text { Glucose }_{\text {biomass }}= & 0.8 \mathrm{Y}_{\mathrm{ATP}}(2 \mathrm{HAc}+3 \mathrm{HPr} \\
& \left.+3 \mathrm{HBu}+\mathrm{CH}_{4}\right),
\end{aligned}
$$


Glucose $_{\text {products }}$

$$
=162 \frac{2 \mathrm{HAc}+3 \mathrm{HPr}+4 \mathrm{HBu}+\mathrm{CO}_{2}+\mathrm{CH}_{4}}{6} .
$$

Total fermentation of hexose-equivalents was calculated as Glucose $_{\text {products }}+$ Glucose $_{\text {biomass. Theoretically, one } \mathrm{mmol}}$ $\mathrm{CO}_{2}$ should be released from the bicarbonate buffer in the medium per mmol VFA produced. This was used to calculate an 'indirect' measure of gas production, which was added to the calculated 'direct' gas, to predict the total gas production. This predicted gas production was then compared with the measured values.

\section{Statistical analysis}

Profiles of cumulative gas (ml/g OM) and VFA (mmol/g $\mathrm{OM})$ production were calculated, as were the degradation and fermentation of $\mathrm{OM}(\mathrm{g} / \mathrm{kg} \mathrm{OM})$. These were fitted iteratively to the model described by Groot et al. (1996) (equation 5). In this equation, $\mathrm{G}(\mathrm{ml} / \mathrm{g} \mathrm{OM}$; mmol/g OM; $\mathrm{g} / \mathrm{kg} \mathrm{OM}$ ) denotes the amount at time $t$ after incubation. $A_{i}$ $(\mathrm{ml} / \mathrm{g} \mathrm{OM} ; \mathrm{mmol} / \mathrm{g} \mathrm{OM}$; $/ \mathrm{kg} \mathrm{OM}$ ) represents the asymptote. $B_{i}(\mathrm{~h})$ is the time after incubation at which half of the asymptotic amount has been formed, and $C_{i}$ is a constant determining the sharpness of the switching characteristic of the profile. The value of $i$ indicates the number of phases in the profile $(i=1, n)$. In this experiment, the monophasic curve $(i=1)$ was used, since only six observations were available per profile.

$$
\mathrm{G}=\sum_{i=1}^{\mathrm{n}} \frac{A_{i}}{1+\frac{B_{i}^{C_{i}}}{t^{C_{i}}}}
$$

Significance of the differences of the parameters was determined by ANOVA. Changes in the proportions of acetic, propionic and butyric acids, and the gas yield during the incubation were analysed by linear regression. Genstat 5.3 (Genstat 5 Committee, 1993) was used for all statistical analyses.

\section{Results}

The crude protein (258 (SE 18.2) $\mathrm{g} / \mathrm{kg} \mathrm{OM}$ ) and ash (213 (SE 6.1) g/ $/ \mathrm{kg} \mathrm{OM}$ ) contents were higher for CC than for $\mathrm{CW}$, which contained 120 (SE 7.0) g crude protein $/ \mathrm{kg} \mathrm{OM}$ and 18 (SE 0.3) $\mathrm{g}$ ash $/ \mathrm{kg} \mathrm{OM}$. NDF content in CW was 771 (SE 14.7) g/kg OM, while this was negligible for $\mathrm{CC}$ and so is not reported here.

\section{Gas and volatile fatty acid production}

The measured cumulative gas production and gas production rates are presented in Fig. 1, while the fitted curve parameters for both measured and predicted gas production are shown in Table 1. Although the final measured gas volumes per $\mathrm{g} O \mathrm{OM}$ were not significantly different between $\mathrm{CC}$ and $\mathrm{CW}$ (Fig. 1(a); Table 1), the maximum gas production rate was higher for CC than for CW (Fig. 1(b)). The maximum gas production rate was reached more rapidly for $\mathrm{CC}$ than for $\mathrm{CW}$. As a consequence, the halftime of the fitted curve (B parameter) occurred later for $\mathrm{CW}$ than for CC.

For the gas production predicted from VFA, the kinetic parameters $\mathrm{B}$ and $\mathrm{C}$ and, thus, the relative gas production rate, were the same as for the measured curves. However, the measured gas volume for $\mathrm{CC}$ was considerably lower than predicted from VFA produced, due to a lower absolute gas production rate, which was most evident during the first $24 \mathrm{~h}$ of the incubation (Fig. 1(b)). For CW the predicted volume of gas produced corresponded closely with the measured value (Table 1).
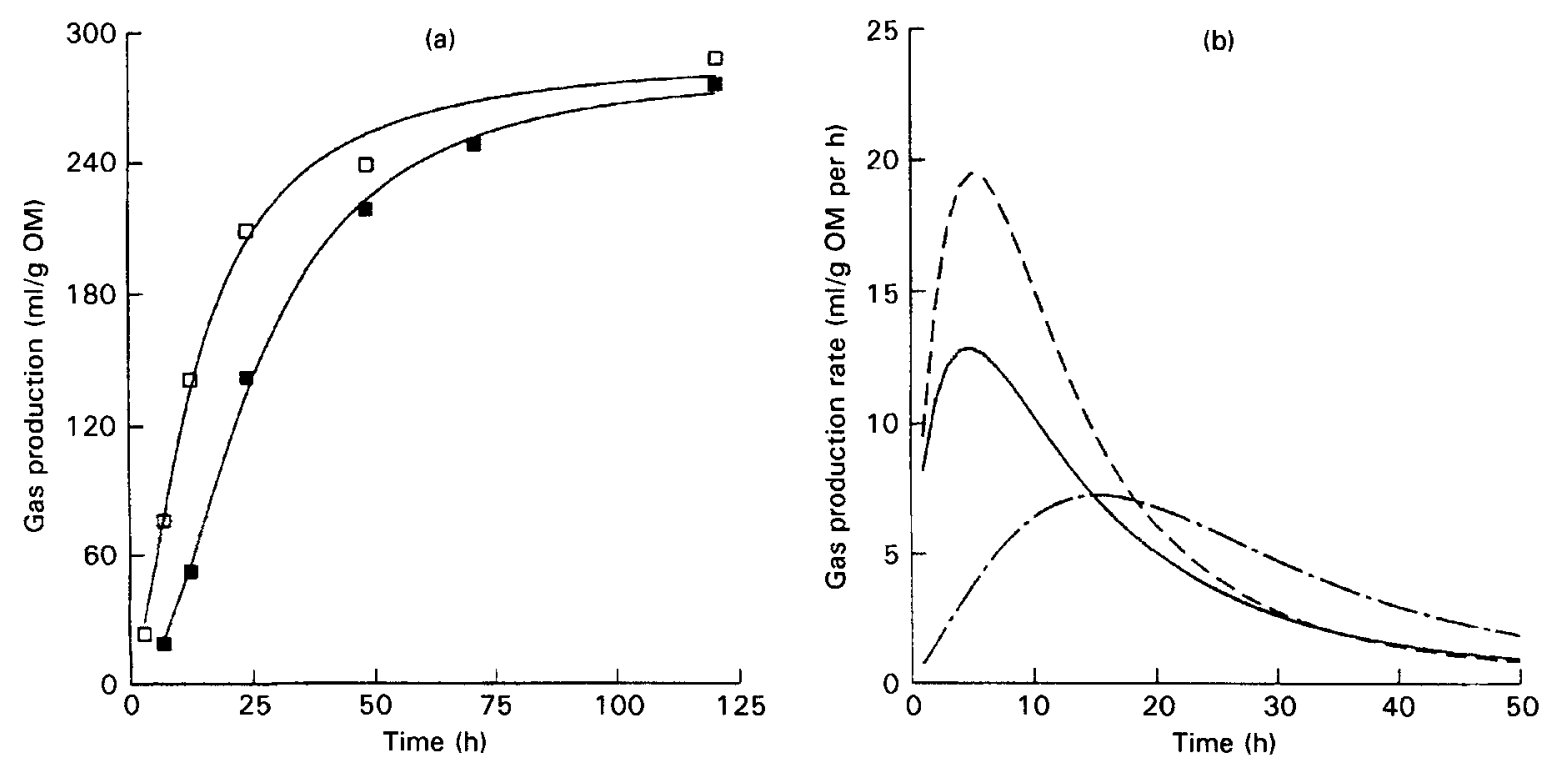

Fig. 1. (a) Measured gas production from cell contents (CC, $\square$ ) and protease-treated cell walls (CW, $\square$ ) of Italian ryegrass during $120 \mathrm{~h}$ fermentation, and the fitted monophasic curves. (b) Gas production rate for CC measured $(\longrightarrow)$ and predicted from volatile fatty acids $(--\rightarrow$, and for $\mathrm{CW}$ measured $(-. \rightarrow$ ) during the first $50 \mathrm{~h}$ of fermentation. Rates were calculated from fitted curves. OM, organic matter. 
Table 1. Mean values* at $120 \mathrm{~h}$ incubation and fitted parameter $A$ for measured and predicted gas production $(\mathrm{ml} / \mathrm{g}$ organic matter $(\mathrm{OM})$ ), volatile fatty acid production $(\mathrm{mmol} / \mathrm{g} O M)$ and $\mathrm{OM}$ fermentability and degradability $(\mathrm{g} / \mathrm{kg} \mathrm{OM})$ for cell contents (CC) and protease-treated cell-wall (CW) fractions of the leaves of Italian ryegrass; fitted half-time $(B, h)$ and the shape parameter $(\mathrm{C})$ are also presented

\begin{tabular}{|c|c|c|c|c|c|}
\hline Variate & Fraction & $120 \mathrm{~h}$ & A & $B$ & $c$ \\
\hline $\begin{array}{l}\text { Measured gas } \\
\text { Predicted gas } \\
\text { LSD }\end{array}$ & $\begin{array}{l}C C \\
C W \\
C C \\
C W\end{array}$ & $\begin{array}{c}287 \\
275 \\
350 \\
274 \\
21.3\end{array}$ & $\begin{array}{l}291 \\
284 \\
362 \\
290 \\
29.4\end{array}$ & $\begin{array}{c}13.8 \\
25.6 \\
11.4 \\
26.5 \\
3.93\end{array}$ & $\begin{array}{l}1.50 \\
2.06 \\
1.70 \\
2.11 \\
0.322\end{array}$ \\
\hline $\begin{array}{l}\text { Measured HAC } \\
\text { Measured HPr } \\
\text { Measured HBu } \\
\text { LSD }\end{array}$ & $\begin{array}{l}\text { CC } \\
\text { CW } \\
C C \\
C W \\
C C \\
C W\end{array}$ & $\begin{array}{l}3.76 \\
3.95 \\
3.23 \\
1.25 \\
0.71 \\
0.32 \\
0.256\end{array}$ & $\begin{array}{l}3.94 \\
4.20 \\
3.32 \\
1.35 \\
0.72 \\
0.37 \\
0.305\end{array}$ & $\begin{array}{c}10.2 \\
28.2 \\
9.6 \\
18.6 \\
13.0 \\
19.7 \\
2.65\end{array}$ & $\begin{array}{l}1.48 \\
2.02 \\
2.35 \\
2.94 \\
2.76 \\
2.31 \\
0.632\end{array}$ \\
\hline $\begin{array}{l}\text { Predicted FOM } \\
\text { Measured DOM } \dagger \\
\text { LSD }\end{array}$ & $\begin{array}{c}\mathrm{CC} \\
\mathrm{CW} \\
\mathrm{CW} \\
\mathrm{CW} \text { corrected } \ddagger\end{array}$ & $\begin{array}{c}847 \\
597 \\
808 \\
603 \\
94.6\end{array}$ & $\begin{array}{l}869 \\
621 \\
928 \\
631 \\
101.1\end{array}$ & $\begin{array}{c}10.2 \\
23.7 \\
19.5 \\
23.8 \\
3.53\end{array}$ & $\begin{array}{l}1.92 \\
2.23 \\
1.18 \\
2.05 \\
0.342\end{array}$ \\
\hline
\end{tabular}

HAc, acetic acid; HPr, propionic acid; HBu, butyric acid; LSD, least significant difference according to the Tukey test ( $\alpha=0.05$ ); FOM, fermentable organic matter; DOM, degradable organic matter.

- All values were corrected for the blank.

+ Not determined for the CC fraction.

$\ddagger \mathrm{CW}$ degradation corrected for the calculated 'lost fraction' of $205 \mathrm{~g} / \mathrm{kg} \mathrm{OM}$ (see p. 524).
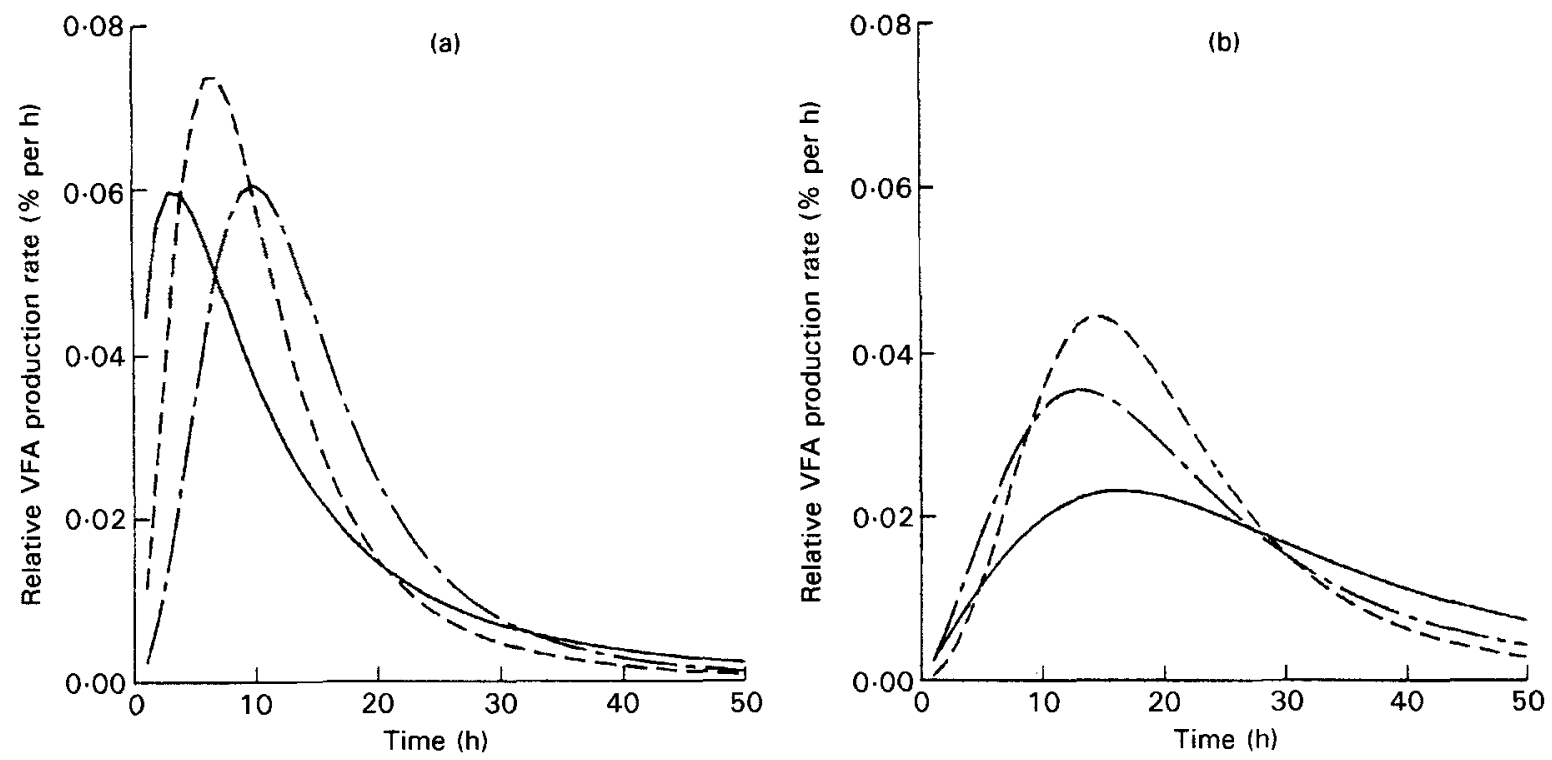

Fig. 2. Relative production rates of acetic acid $(-)$, propionic acid (- - ) and butyric acid (-.-) from (a) cell contents and (b) protease-treated cell walls of Italian ryegrass during the first $50 \mathrm{~h}$ of incubation. Relative rates were calculated from fitted curves. VFA, volatile fatty acids.

After $120 \mathrm{~h}$ of incubation, 11.0 (SE 0.53 ) and 8.2 (SE $0.29) \mathrm{mmol}$ VFA/g OM had been produced from CC and $\mathrm{CW}$ respectively. For both fractions, $89 \%$ of the total VFA consisted of acetic, propionic and butyric acids. The amounts and kinetics of VFA production are presented in Table 1 and Fig. 2 and molar percentages of these acids are shown in Fig. 3.

Two phases could be distinguished in the changes of the proportions of VFA for CC. Until $24 \mathrm{~h}$ of incubation, the proportion of acetic acid declined and propionic and later butyric acid proportions increased (Fig. 3(a)). After $24 \mathrm{~h}$ of incubation, there was a linear increase in the proportion of acetic acid and a decrease in the proportion of propionic acid (both $P<0.001$ ). These trends could be related to the changes in the relative rates of VFA production (Fig. 2(a)). A succession of maxima in the relative production rates of acetic, propionic and butyric acids occurred, after 3, 7 and $10 \mathrm{~h}$ of incubation respectively. After the maxima had been 

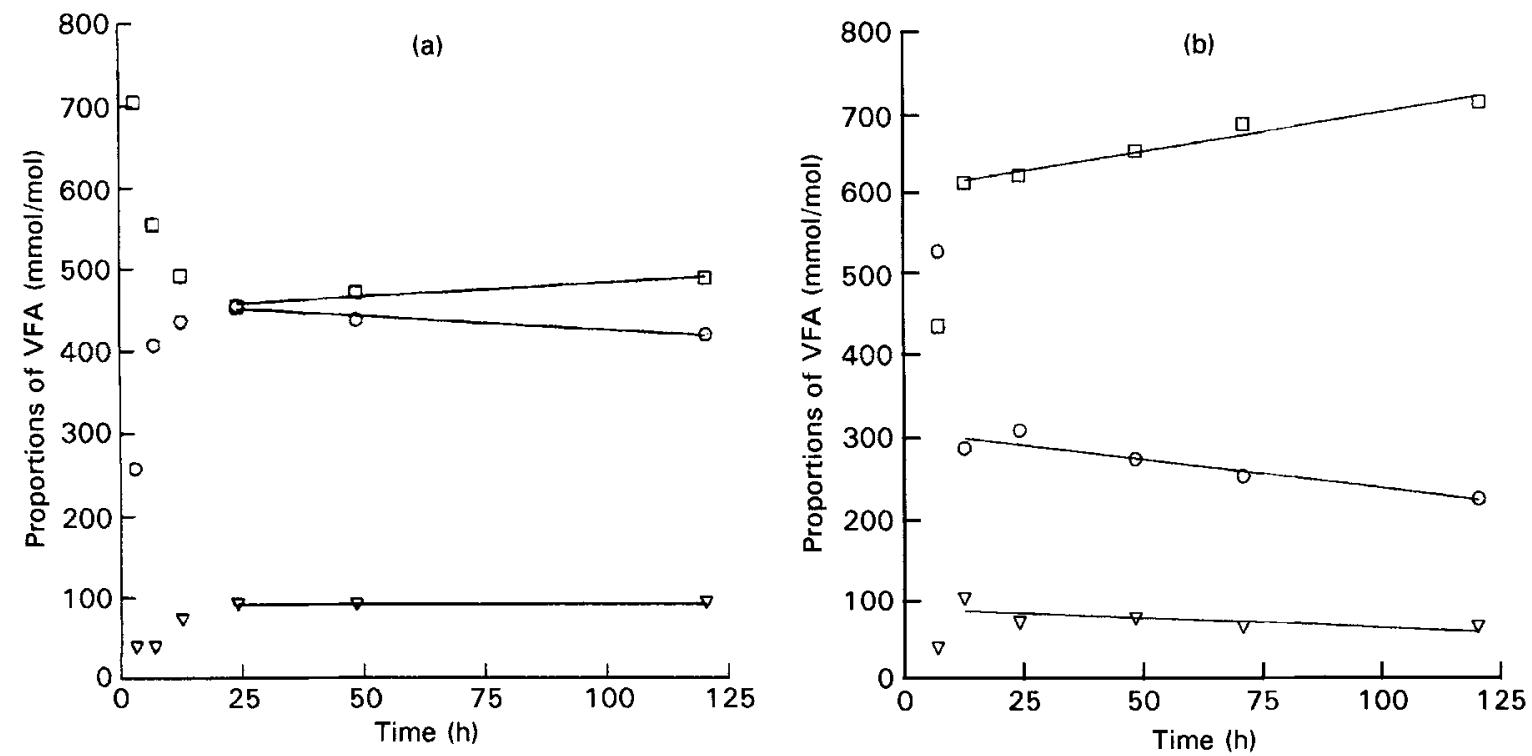

Fig. 3. Proportions of the total volatile fatty acids (VFA) occurring as acetic acid $(\square)$, propionic acid $(O)$ and butyric acid $(\nabla)$ during $120 \mathrm{~h}$ fermentation of (a) cell contents and (b) protease-treated cell walls of Italian ryegrass. The lines indicate the significant linear relationship determined by regression analysis after $24 \mathrm{~h}$ and $12 \mathrm{~h}$ incubation for cell contents and cell walls respectively.

reached, the relative production rates declined rapidly for all VFA, though more so for propionic and butyric acid than for acetic acid.

For $\mathrm{CW}$, rapid changes in the proportions of VFA occurred between 6 and $12 \mathrm{~h}$ of incubation (Fig. 3(b)). After $12 \mathrm{~h}$ of incubation, changes were more gradual, with an increase in the proportion of acetic acid, and declining propionic and butyric acid proportions $(P<0.001)$. The propionic acid production was lower than with CC (Table 1). As a result the proportions of acetic and butyric acid in total VFA were higher. The maxima in the relative production rates of VFA occurred almost simultaneously, but the relative rate of acetic acid production levelled off more slowly than for propionic and butyric acids (Fig. 2(b)).

\section{Degradation, fermentation, and gas yield}

Stoichiometric equations were also used to predict how much OM should have been fermented to produce the amounts of VFA measured from CC and CW (Fig. 4(a)).
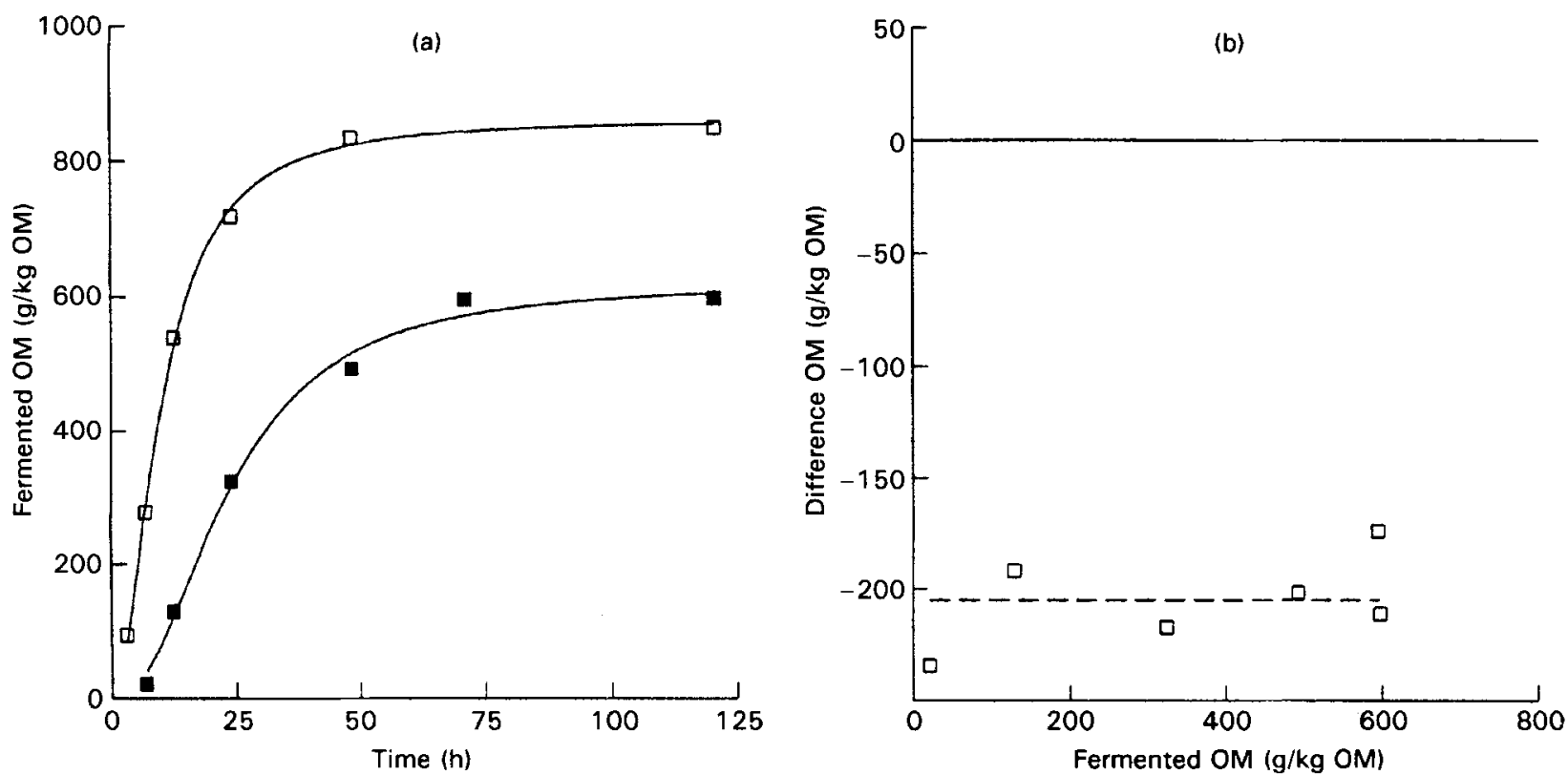

Fig. 4. (a) Stoichiometrically calculated organic matter (OM) fermentability for cell contents $(\square)$ and protease-treated cell walts ( $\square$ ) from ltalian ryegrass, and the fitted monophasic curves. (b) The difference between predicted OM fermentability and measured OM degradability $v$. predicted OM fermentability. (...), Average value. 

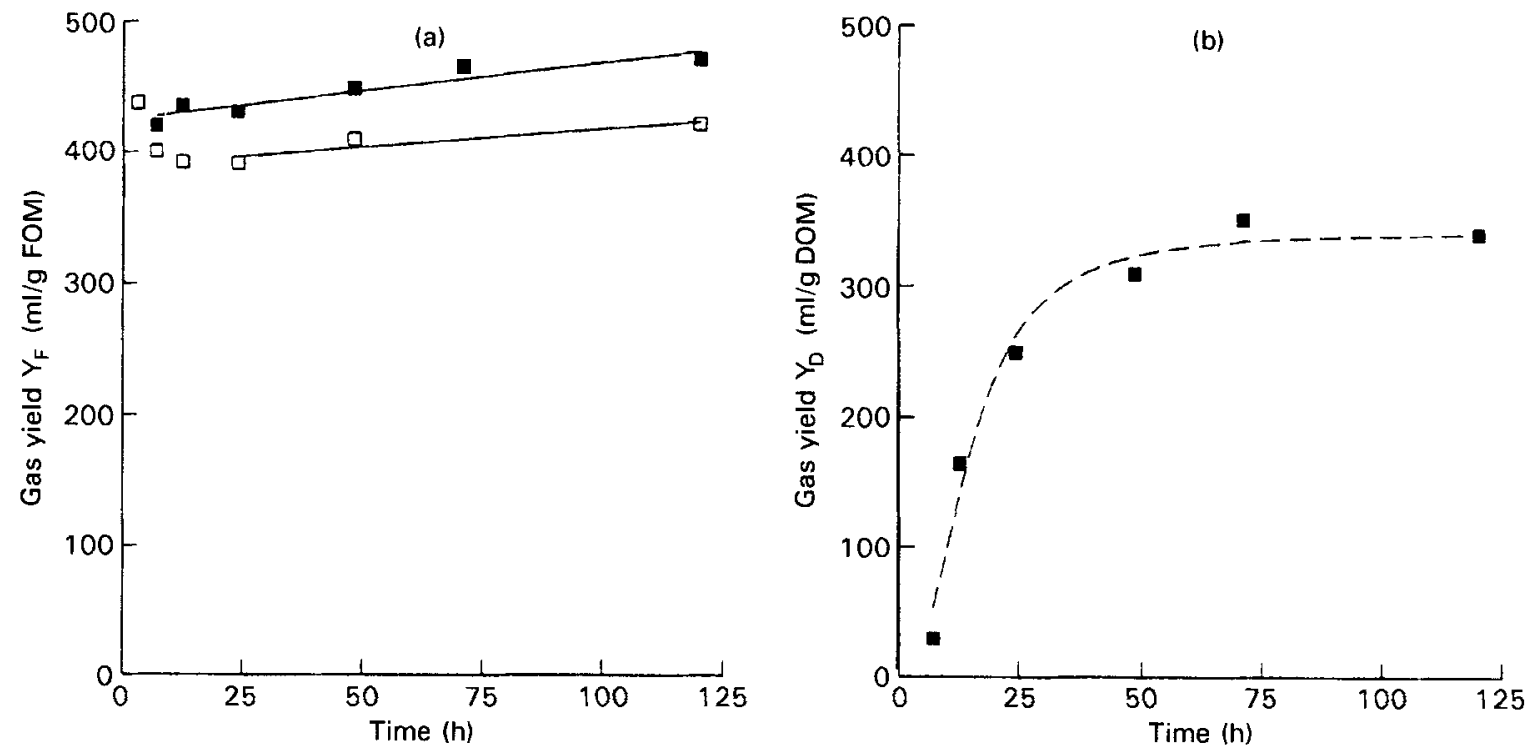

Fig. 5. (a) Changes in predicted fermentative yield of gas $\left(Y_{F} ; \mathrm{ml} / \mathrm{g}\right.$ predicted fermentable organic matter (FOM)) for cell contents $(\square)$ and protease-treated cell walls $(\square)$ of Italian ryegrass. (b) Changes in measured degradative yield of gas $\left(\mathrm{Y}_{\mathrm{D}} ; \mathrm{ml} / \mathrm{g}\right.$ measured degradable organic matter (DOM)) for protease-treated cell walls (a).

The predicted final fermentability of both $\mathrm{CC}$ and $\mathrm{CW}$ was considerably lower than $100 \%$ (Table 1 ).

Fig. 4(b) shows that for $\mathrm{CW}$ the predicted $\mathrm{OM}$ fermentability was 205 (SE 21.0) g/ kg OM lower than the measured degradability. This difference was considered to be a 'lost fraction'. Moreover, the asymptotic gas volume A was higher and the kinetic parameters $B$ and $C$ were lower than for the measured degradation. However, when the degradability was corrected for the 'lost fraction' of $205 \mathrm{~g} / \mathrm{kg} \mathrm{OM}$ at every point of observation, the fitted parameters of degradability of $\mathrm{CW}$ corresponded with those of fermentability (Table 1 ).

The yields of gas per $g$ fermented $\mathrm{OM}\left(\mathrm{Y}_{\mathrm{F}}\right)$ and per $\mathrm{g}$ degraded $\mathrm{OM}\left(\mathrm{Y}_{\mathrm{D}}\right)$ are shown in Fig. 5(a) and 5(b). For CC, $\mathrm{Y}_{\mathrm{F}}$ declined until $24 \mathrm{~h}$ of incubation and increased thereafter $(P<0.001)$. The $\mathrm{Y}_{\mathrm{F}}$ from $\mathrm{CW}$ increased linearly throughout the incubation. $Y_{D}$ for $C W$ (Fig 5(b)) increased throughout the incubation period to reach a maximum of $340 \mathrm{ml}$ gas/g degradable $\mathrm{OM}$. $\mathrm{Y}_{\mathrm{D}}$ was consistently lower than $\mathrm{Y}_{\mathrm{F}}$.

\section{Discussion}

The results suggest that gas production profiles are not necessarily linearly related to degradation or fermentation of substrate. The higher predicted compared with measured gas production for $\mathrm{CC}$ indicated that the stoichiometric relations (Van Soest, 1994) are probably not valid for rapidly fermenting substrates.

For CC, the approximately $25 \%$ higher gas production predicted by stoichiometric calculations than measured was similar to overestimations of gas production reported for cellulose (by $20 \%$ ) and glucose (by $10 \%$ ) by Beuvink \& Spoelstra (1992). Typically, these overestimations occur for substrates producing high proportions of propionic acid. The use of pure substrates by Beuvink \& Spoelstra (1992) seems to rule out the possible mechanism of reduction of gas production by bonding of $\mathrm{CO}_{2}$ to $\mathrm{NH}_{3}$. A second process which could reduce the gas produced per mol VFA, would be the conversion of $\mathrm{CO}_{2}$ and $\mathrm{H}_{2}$ to acetate instead of $\mathrm{CH}_{4}$ (Miller, 1995), which would result in the net consumption of one mol $\mathrm{CO}_{2}$. This process mainly occurs when low roughage diets containing high proportions of sugars and protein are fed (Leedle \& Greening, 1988). The possible role of this process could not be estimated for the present experiment as the gases were not analysed. A third possibility could relate to the large crude protein fraction of CC. Little work has been done in the area of the stoichiometric relations for the fermentation of protein, and it is likely that these differ from those for hexose equivalents. This suggests that care must be taken with stoichiometric balances for feedstuffs which contain large amounts of protein.

Relatively large amounts of propionic and butyric acid from $\mathrm{CC}$ are more frequently reported when easily digestible substrates are supplied to rumen microbes (Van Houtert, 1993). When the rate of gas production was high, the proportions of propionic and butyric acid increased and consequently the calculated gas yield $\left(\mathrm{Y}_{\mathrm{F}}\right)$ was low. After $24 \mathrm{~h}$ of incubation, the gas production rate was lower, and mainly acetic acid was produced which led to an increase in $\mathrm{Y}_{\mathrm{F}}$. This corresponds with the more frequently observed two-phasic gas production (e.g. Pell \& Schofield, 1993; Groot et al. 1996). However, multiphasic analysis of the gas production profiles was not possible, due to the limited number of observations per curve.

For $\mathrm{CW}$, the value of $\mathrm{Y}_{\mathrm{F}}$ increased throughout the incubation, due to the higher production of acetic acid compared with other VFA. This resulted in a higher halftime (B parameter) for gas production $(26.5 \mathrm{~h}$ ) than for fermentation of OM $(23.7 \mathrm{~h})$. The value of $Y_{D}$ increased even more rapidly, and could probably be attributed to the loss of some material when the residual $\mathrm{CW}$ was 
determined by use of neutral detergent (Goering \& Van Soest, 1970). This 'lost' CW fraction may have been a component such as soluble lignin-carbohydrate complexes (Chesson, 1993), which are not fermentable. Such a loss of CW was probably also the cause of the overestimation of gas production by Blümmel \& Ørskov (1993), which they attributed to substrate trapping by microbes.

In conclusion, the fermentation studies resulting in gas and VFA production date can give more insight into the processes occurring in in vitro forage evaluation systems. The results also indicate that caution is required in the interpretation of gas production profiles particularly for forages of heterogeneous composition. For forage evaluation, it is important to distinguish between degradation and fermentation, as not all degraded CW material is necessarily fermentable.

\section{Acknowledgements}

The authors would like to thank André Maassen and Marianne van't End for their help with the gas readings, and Dick Bongers of the Department of Human and Animal Physiology for help with the VFA analysis.

\section{References}

Beuvink JMW \& Spoelstra SF (1992) Interactions between substrate, fermentation end-products, buffering systems and gas production upon fermentation of different carbohydrates by mixed rumen organisms in vitro. Applied Microbiology and Biotechnology 37, 505-509.

Blümmel M \& Ørskov ER (1993) Comparison of in vitro gas production and nylon bag degradability of roughages in predicting feed intake in cattle. Animal Feed Science and Technology 40, 109-119.

Chesson A (1993) Mechanistic models of forage cell-wall degradation. In Forage Cell-wall Structure and Digestibility, pp. 347-376 [HG Jung, DR Buxton, RD Hatfield and J Ralph, editors]. Madison, WI: American Society of Agronomy.

Erwin ES \& Elliston NG (1959) Rapid method of determining digestibility of concentrates and roughages in cattle. Journal of Animal Science 18, 1518.

Genstat 5 Committee (1993) Genstat 5 Release 3 Reference Manual. Oxford: Clarendon Press.

Goering HK \& Van Soest PJ (1970) Forage Fiber Analysis. Agricultural Handbook 279. Washington, DC: United States Department of Agriculture.

Groot JCJ, Cone J, Williams BA, Debersaques FD \& Lantinga EA (1996) Multiphasic analysis of gas production kinetics for in vitro fermentation of ruminant feeds. Animal Feed Science and Technology 64, 77-89.

Hespel RB (1979) Efficiency of growth by ruminal bacteria. Federation Proceedings 38, 2707-2712.

Hungate RE (1966) The Rumen and Its Microbes. New York, NY: Academic Press.
Leedle JAZ \& Greening RC (1988) Postprandial changes in methanogenic and acidogenic bacteria in the rumens of steers fed high- or low-forage diets once daily. Applied and Environmental Microbiology 54, 502-506.

Lin KW, Patterson JA \& Ladish MR (1985) Anaerobic fermentation: microbes from ruminants. Enzyme Microbiology and Technology 7, 98-107.

McAllister TA, Bae HD, Jones GA \& Cheng K-J (1994) Microbial attachment and feed digestion in the rumen. Journal of Animal Science 72, 3004-3018.

Merchen NR \& Bourquin LD (1994) Processes of digestion and factors influencing digestion of forage-based diets by ruminants. In Forage Quality, Evaluation, and Utilization, pp. 564 612 [GC Fahey Jr, editor]. Madison, WI: American Society of Agronomy.

Miller TL (1995) Ecology of methane production and hydrogen sinks in the rumen. In Ruminant Physiology: Digestion, Metabolism, Growth and Reproduction, pp. 317-331 [E Von Engelhardt, S Leonhard-Marek, G Breves and D Giesecke, editors]. Stuttgart: Ferdinand Enke Verlag.

Ørskov ER, Hovell FDDeB \& Mould F (1980) The use of the nylon bag technique for the evaluation of feedstuffs. Tropical Animal Production 5, 195-213.

Pell AN \& Schofield P (1993) Computerized monitoring of gas production to measure forage digestion in vitro. Joumal of Dairy Science 76, 1063-1073.

Russell JB \& Wallace RJ (1988) Energy yielding and consuming reactions. In The Rumen Microbial Ecosystem, pp. 185-215 [PN Hobson, editor]. Essex: Elsevier.

Salvador V, Cherbut C, Barry J-L, Bertrand D, Bonnet C \& Delort-Laval J (1993) Sugar composition of dietary fibre and short-chain fatty acid production during in vitro fermentation by human bacteria. British Journal of Nutrition 70, 189-197.

Steiner AA (1984) The universal nutrient solution. In Proceedings of the VIth International Congress on Soilless Culture, pp. 633650. Wageningen, The Netherlands: Secretariat of the International Society for Soilless Culture, ISOSC.

Theodorou MK, Williams BA, Dhanoa MS, McAllan AB \& France J (1994) A simple gas production method using a pressure transducer to determine the fermentation kinetics of ruminant feeds. Animal Feed Science and Technology 48, 185-197.

Tilley JMA \& Terry RA (1963) A two-stage technique for the invitro digestion of forage crops. Journal of the British Grassland Society 18, 104-111.

Van Houtert MFJ (1993) The production and metabolism of volatile fatty acids by ruminants fed roughages: a review. Animal Feed Science and Technology 43, 189-225.

Van Soest PJ (1994) Nutritional Ecology of the Ruminant: Ruminant Metabolism, Nutritional Strategies, the Cellulolytic Fermentation and the Chemistry of Forages and Plant Fibers. Oregon: O\&B Books Inc.

Wolin MJ (1975) Interactions between bacterial species in the rumen. In Digestion and Metabolism in the Ruminant, pp. 1452-1459 [IW McDonald and AC Warner, editors]. Armidale: The University of New England Publishing Unit.

Wolin MJ (1979) The rumen fermentation: a model for microbial interactions in anaerobic ecosystems. Advances in Microbial Ecology 3, 49-77. 